\title{
Mineralogy, geochemistry, petrography, and depositional environment of Gebel El-Qurn, Early Eocene, West Luxor, South Egypt
}

Esmat A. Abou El-Anwar *iD, H. S. Mekky and S. H. Abd El Rahim

\begin{abstract}
Background: Luxor represented the modern Egyptian city that occupies the site of ancient Thebes. Thebes Mountain on the West Bank of the Nile, opposite the town of Luxor, is among the most famous historical sites of the world. Carbonate rocks exposed at Gebel El-Qurn, west Luxor, south Egypt has been investigated for mineralogical, petrographical, and geochemical studies to illustrate its depositional environments.

Results: We revealed that the carbonate rocks in the Gebel El-Qurn, west Luxor, are mainly of Lower Eocene age. The carbonate rocks that belong to the Thebes Formation were deposited under shallow, warm, oxidizing, open marine environment. Petrographically, they are differentiated into five microfacies: (1) nummulitic bioclastic wackestone/ mudstone, (2) nummulitic biosparite grainstone, (3) nummulitic rudstone microfacies, (4) pelecypod biomicrite wacke/ packstone, and (5) biomicrite dolomitic lime-mudstone. Diagenetically, carbonate rocks were subjected to cementation, compaction, neomorphism, dissolution, and dolomitization processes. Mineralogically, XRD revealed that the studied carbonate samples consist mainly of calcite as well as dolomite, quartz, halite, pyrite, and clay minerals. EDX data indicated that the dolomite of the Gebel El-Qurn is non-stoichiometric in composition, and the size of crystals is up to $80 \mu \mathrm{m}$.

Geochemically, the carbonate rocks of the Gebel El-Qurn are impoverished in Sr and Na content. This may be attributed to the diagenetic processes, which took place under less saline environment than seawater. Dolomite crystals were formed by re-crystallization under mixed marine-meteoric environment. The positive correlation between $\mathrm{Sr}$ and $\mathrm{Fe}_{2} \mathrm{O}_{3}$ indicates that the studied carbonates were deposited under control of bacterial activity. The studied carbonate rocks are characterized by light REE (LREE) enrichment with respect to heavy REE (HREE). The total radioactivity measurements are ranging from 4 to $5.9 \mathrm{ppm}$ for $U$ and from 5.5 to $6.6 \mathrm{ppm}$ for Th. The radioactivity measurements are less than the background level of carbonates, and they are in the permissible limits for carbonates used in cement industries and as building stones.
\end{abstract}

Conclusions: The petrographical and geochemical observations, as well as mineralogical investigation, indicate that the carbonate rocks in the Gebel El-Qurn were deposited in a shallow, warm open marine environment.

Keywords: Gebel El-Qurn, Thebes Formation, Petrography, Geochemistry, Rare earth elements

\footnotetext{
* Correspondence: abouelanwar2004@yahoo.com

Geological Sciences Department, National Research Centre, 33 El Bohouth St. (former El Tahrir St.)-Dokki, POB: 12622, Giza, Egypt
} 


\section{Background}

Luxor, the modern Egyptian city that occupies the site of ancient Thebes, is famed for its magnificent ancient monuments. The Thebes Mountain on the West Bank of the Nile, opposite the town of Luxor, is among the most famous historical sites of the world. The Thebes Mountains are sedimentary rocks that are composed mainly of shales, marls, chalk, and limestones. They consist of three important formations, from base to top, the Paleocene Tarawan Chalk, the Paleocene/Eocene Esna Shale, and the Lower Eocene Thebes Formation which were unconformably overlain by the Plio-Pleistocene conglomerate (Said 1962). Generally, they were mainly deposited through the Paleocene-Lower Eocene age in a pelagic and shallow environment under and above the phototropic zone (Said 1990). Thebes Mountains in Luxor were studied by many authors: biostratigraphy (Perch-Nielsen et al. 1978; Strougo and Hassaan 1984), sedimentology, and structural geology (Yehia 1986; El-Kammar et al. 1991; Elwaseif et al. 2012), in addition, recently, the environmental studies (El-Bayomi 2007; Leisen et al. 2008).

The stratigraphic succession of Gebel El-Qurn, west Luxor, is represented as a type-section of the Thebes Formation (Said 1962). The succession belongs to the Thebes Mountains that extend for several hundred kilometers toward the west of the western side of the Nile River. These mountains consist of craggy limestone hills which have been deeply incised by a series of dendritic wadis that mainly controlled by gravity, structure, and/or lithology (Yehia 1973). The maximum elevation is more than $400 \mathrm{~m}$ from the Nile River to the top of Gebel El-Qurn.

The present study uses incorporated petrographical, geochemical, and mineralogical studies in order to decide the origin and the depositional environments of the carbonate rocks of Member IV, Lower Eocene, Thebes Formation of Gebel El-Qurn in west Luxor, south Egypt (Fig. 1).

\section{Methods}

Twenty representative samples were collected from the carbonate beds of Gebel El-Qurn in west Luxor, in the south part of Egypt. Mineralogically, four selected samples were investigated by the X-ray technique at the Egyptian Mineral Resources Authority (Dokki, Egypt) using a PAN analytical X-ray diffraction equipment model $X^{\prime}$ Pert PRO with Secondary Monochromator, Cu-radiation $(\lambda=$ $1.542 \AA$ ) at 45 K.V., 35 M.A., and a scanning speed of $0.02 \%$ sere used. The diffraction charts and relative intensities are compared with ICDD files. The morphology and the size of the synthesized samples were examined using scanning electron microscope carried out in the nuclear materials as well as the thin sections under microscope. Ten samples were selected to determine the chemical composition by using Axios Sequential WD_XRF Spectrometer, Analytical 2005 in the National Research
Center laboratories, ASTM E 1621 standard guide for elemental analysis by wavelength dispersive X-Ray Fluorescence Spectrometer, and ASTM D 7348 standard test methods for loss of ignition (LOI) of solid combustion. The fabric and the size of the synthesized samples were characterized via SEM coupled with energy-dispersive spectroscopy EDAX (SEM Model Quanta FEG 250), carried out in the National Research Center laboratories.

\section{Geologic setting}

The stratigraphic succession at Gebel El-Qurn, west Luxor, comprising the Esna Shale and Thebes Formations, reaches about $400 \mathrm{~m}$ thick (Fig. 2), which ranges from the upper Paleocene to the lower Eocene.

The Thebes Formation is about $350 \mathrm{~m}$ thick and commences with fine-grained micritic limestone and marl rich in bands and nodules of chert, probably deposited at bathyal depths (Snavely et al. 1978), and ends with repetitive skeletal limestones and oyster banks formed in a shallow water setting. Said (1962) classified the Thebes Formation into four members according to variations in lithology and weathering characteristics (Fig. 2).

Member IV was composed of about $250 \mathrm{~m}$ of an alternating series of dolomitic limestones, marls, shales, and nodular limestones with interbedded chert nodules and chert bands.

They are regarded as individual shallowing upward cycles of deposition. In addition, they are richly fossiliferous, with cephalopods (Nautilus sp.), gastropods (Turritella sp.), pelecypods (Ostrea sp.), and anodont bivalves (Lucina thebaica), and various nummulites and Operculina sp. They were deposited in shallow water $(10-100 \mathrm{~m})$ on an extensive carbonate platform (Wüst 1995).

\section{Results}

Mineralogically, the studied carbonate rocks consist of six minerals, mainly of calcite as well as dolomite, quartz, halite, pyrite, and clay minerals. Petrographically, five major microfacies were encountered in the studied section. Five main diagenetic features encountered in the carbonate rocks of Geble El Gurna. Chemical analysis data for major, trace, and rare earth elements of the studied carbonate rocks are listed in Table 1 and the relation between them in Table 2 .

\section{Discussion \\ Mineralogy}

$\mathrm{X}$-ray patterns revealed that the dominating minerals in the studied samples are mainly calcite as well as dolomite, quartz, halite, pyrite, and clay minerals. The EDX analysis data for the bulk samples show that this phase of dolomite is nearly stoichiometry $(\mathrm{Mg}: \mathrm{Ca} \approx 1: 1)$ and the size of the dolomite crystals is up to $80 \mu \mathrm{m}$ without any zoning. Also, present of halite which conformed with the X-ray analysis. 


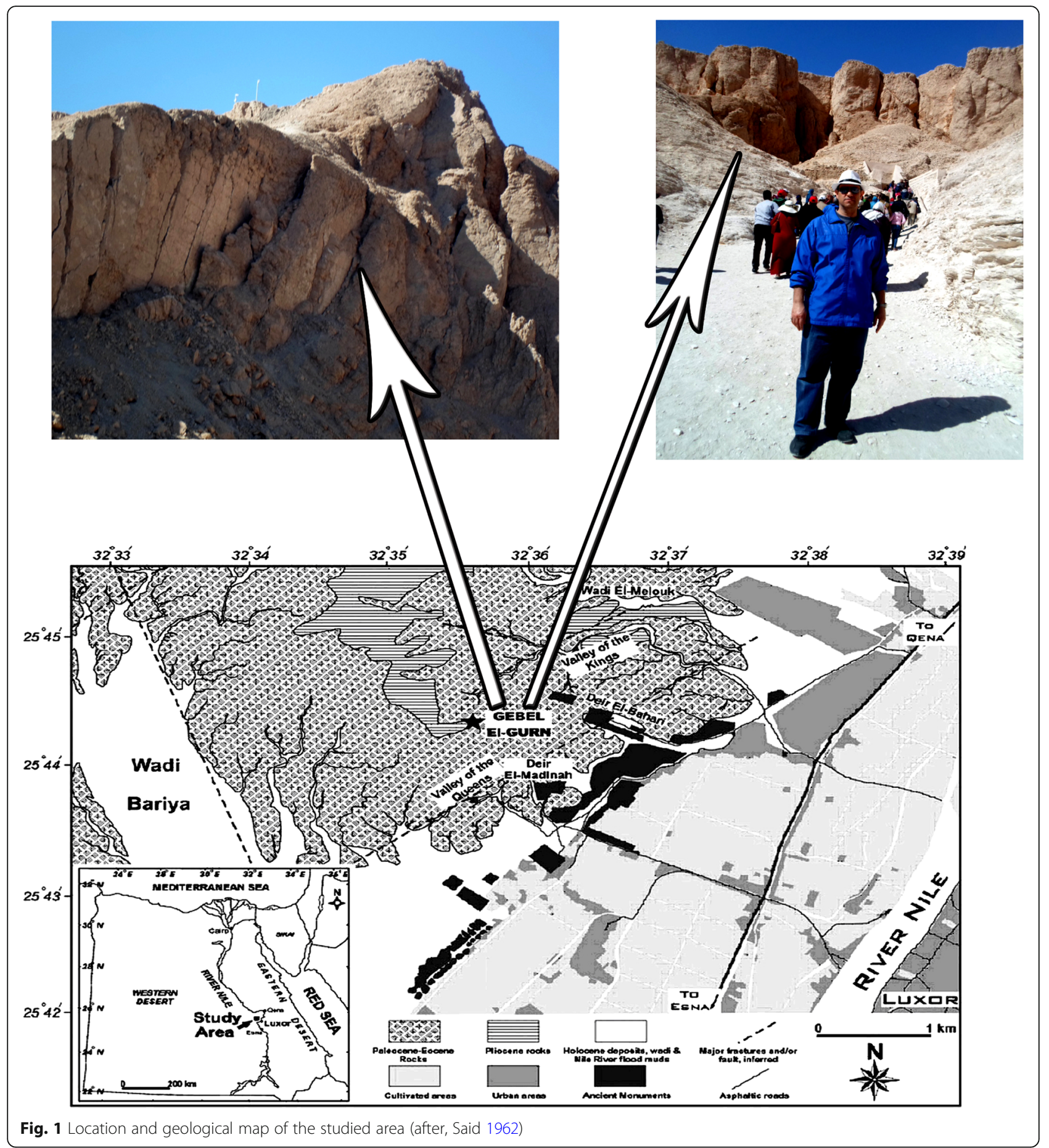

Dolomite crystals are unimodal and polymodal; planar-e and planar-s as well as some are interlocked (Fig. 3). Also, the photo is showing patches from disorder from halite crystals, which is conformed with X-ray results.

\section{Petrography}

The faunal assemblage that characterizes the studied succession consists of forminifera, Nummulites, pelecypods, miliolids as well as echinods fragments, and others. Petrographically, five major microfacies were encountered in the studied section:

Nummulitic biomicrite wackestone/mudstone microfacies This microfacies is the most prevailing microfacies in the studied section of Gebel El-Qurn. It consists mainly of $35 \%$ fossils and $4 \%$ quartz grains embedded in micrite 


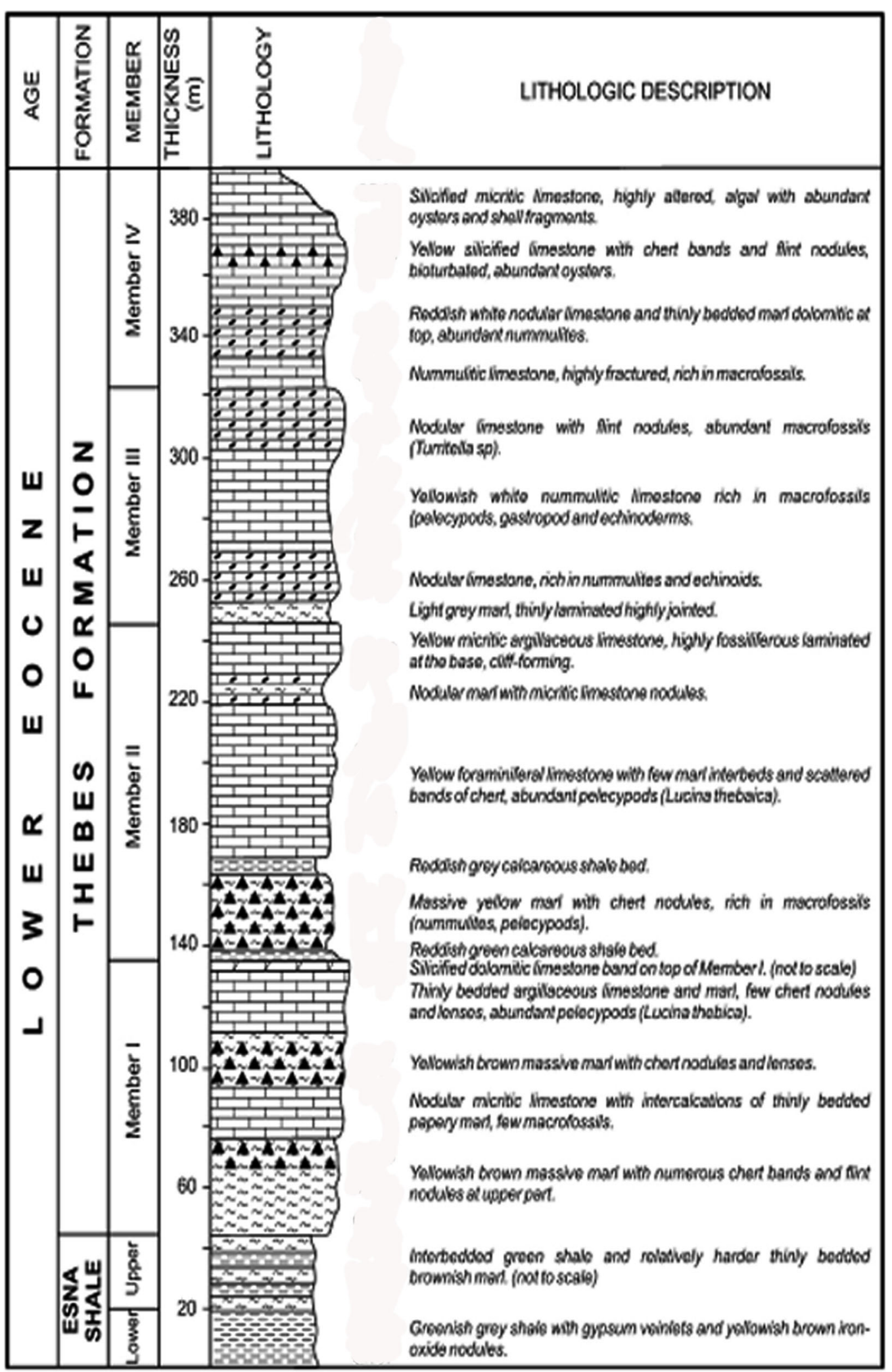

Fig. 2 Lithostratigraphic succession of Gebel El-Qurn, west Luxor, southern Egypt (after Said 1962) 
Table 1 Chemical analysis data of major oxides (\%) and trace rare earth elements (ppm), of the studied rocks

\begin{tabular}{|c|c|c|c|c|c|c|c|c|c|c|c|c|c|}
\hline & 1 & 2 & 3 & 4 & 5 & 6 & 7 & 8 & 9 & 10 & Mim. & Max. & Average \\
\hline $\mathrm{CaO}$ & 50.84 & 32.21 & 48.21 & 51.36 & 50.84 & 48.27 & 51.21 & 49.51 & 50.41 & 38.44 & 32.21 & 51.36 & 47.13 \\
\hline $\mathrm{MgO}$ & 3.26 & 1.01 & 2.11 & 0.8 & 3.51 & 3.85 & 2.57 & 1.92 & 2.1 & 2.04 & 0.8 & 3.85 & 2.317 \\
\hline $\mathrm{SiO}_{2}$ & 2.33 & 23.74 & 5.34 & 3.25 & 1.25 & 3.45 & 4.52 & 3.55 & 3.24 & 18.75 & 1.25 & 23.74 & 6.942 \\
\hline $\mathrm{Al}_{2} \mathrm{O}_{3}$ & 0.63 & 0.81 & 1.95 & 0.98 & 0.51 & 1.97 & 1.92 & 0.95 & 0.92 & 0.8 & 0.51 & 1.97 & 1.144 \\
\hline $\mathrm{Fe}_{2} \mathrm{O}_{3}$ & 0.76 & 0.64 & 0.84 & 0.78 & 0.82 & 0.89 & 0.74 & 0.81 & 0.91 & 0.85 & 0.64 & 0.91 & 0.804 \\
\hline $\mathrm{Na}_{2} \mathrm{O}$ & 0.11 & 0.1 & 0.21 & 0.12 & 0.11 & 0.15 & 0.16 & 0.19 & 0.18 & 0.12 & 0.1 & 0.21 & 0.145 \\
\hline $\mathrm{K}_{2} \mathrm{O}$ & 0.03 & 0.03 & 0.02 & 0.03 & 0.03 & 0.03 & 0.02 & 0.03 & 0.02 & 0.03 & 0.02 & 0.03 & 0.027 \\
\hline $\mathrm{P}_{2} \mathrm{O}_{5}$ & 0.22 & 0.25 & 0.24 & 0.26 & 0.27 & 0.25 & 0.3 & 0.22 & 0.24 & 0.25 & 0.22 & 0.3 & 0.25 \\
\hline $\mathrm{Cl}$ & 0.08 & 0.09 & 0.11 & 0.01 & 0.09 & 0.14 & 0.2 & 0.15 & 0.15 & 0.11 & 0.01 & 0.2 & 0.113 \\
\hline LOI & 41.6 & 41.02 & 41.11 & 41.91 & 41.82 & 40.97 & 38.74 & 42.51 & 41.65 & 38.57 & 38.57 & 42.51 & 40.99 \\
\hline $\mathrm{Ti}$ & 60 & 77 & 65 & 70 & 62 & 75 & 55 & 88 & 50 & 80 & 50 & 88 & 68 \\
\hline $\mathrm{Sr}$ & 445 & 510 & 400 & 470 & 520 & 490 & 460 & 510 & 500 & 520 & 400 & 520 & 483 \\
\hline Sc & 30 & 35 & 25 & 24 & 20 & 19 & 29 & 28 & 32 & 22 & 19 & 35 & 26.4 \\
\hline V & 24.5 & 29 & 35 & 28 & 26 & 30 & 19 & 22.5 & 23.4 & 24.3 & 19 & 35 & 26.17 \\
\hline $\mathrm{Cr}$ & 34.6 & 35 & 38 & 37 & 36.4 & 40 & 23.8 & 37 & 34.5 & 33.8 & 23.8 & 40 & 35.01 \\
\hline $\mathrm{Mn}$ & 50.2 & 52 & 48 & 55 & 59 & 58 & 60 & 55.4 & 36.5 & 49.7 & 36.5 & 60 & 52.38 \\
\hline Co & 0.4 & 0.5 & 0.3 & 0.6 & 0.4 & 0.8 & 0.7 & 0.5 & 0.4 & 0.3 & 0.3 & 0.8 & 0.49 \\
\hline $\mathrm{Ni}$ & 10.8 & 11.5 & 12 & 14.2 & 11.5 & 15.1 & 14.2 & 13.4 & 12.7 & 13.7 & 10.8 & 15.1 & 12.91 \\
\hline $\mathrm{Cu}$ & 5.8 & 6.1 & 6.5 & 5.8 & 5.9 & 4.9 & 6.2 & 7.1 & 6.8 & 6.9 & 4.9 & 7.1 & 6.2 \\
\hline $\mathrm{Zn}$ & 54.4 & 57.4 & 55.3 & 60.2 & 62.3 & 59 & 58.1 & 57.5 & 61.5 & 62.4 & 54.4 & 62.4 & 58.81 \\
\hline Ga & 0.5 & 0.4 & 0.4 & 0.3 & 0.5 & 0.5 & 0.06 & 0.03 & 0.04 & 0.05 & 0.03 & 0.5 & 0.278 \\
\hline As & 0.8 & 0.7 & 0.6 & 0.5 & 0.5 & 0.6 & 0.3 & 0.4 & 0.7 & 0.8 & 0.3 & 0.8 & 0.59 \\
\hline Se & 0.6 & 0.04 & 0.05 & 0.06 & 0.06 & 0.08 & 0.07 & 0.06 & 0.05 & 0.06 & 0.04 & 0.6 & 0.113 \\
\hline $\mathrm{Br}$ & 1.5 & 1.3 & 1.5 & 2.1 & 2.4 & 1.9 & 1.6 & 1.5 & 2.2 & 1.8 & 1.3 & 2.4 & 1.78 \\
\hline Mo & 2 & 3 & 2.4 & 1.8 & 2.5 & 2.7 & 3 & 3.5 & 3.8 & 3.8 & 1.8 & 3.8 & 2.85 \\
\hline Y & 0.8 & 0.9 & 0.7 & 0.8 & 0.6 & 0.9 & 0.8 & 0.6 & 0.8 & 0.8 & 0.6 & 0.9 & 0.77 \\
\hline $\mathrm{Zr}$ & 5.5 & 7.4 & 6.8 & 5.9 & 5.8 & 6.5 & 7 & 7.5 & 6.4 & 5.9 & 5.5 & 7.5 & 6.47 \\
\hline $\mathrm{Ag}$ & 0.1 & 0.1 & 0.1 & 0.1 & 0.2 & 0.1 & 0.1 & 0.2 & 0.1 & 0.1 & 0.1 & 0.2 & 0.12 \\
\hline As & 0.8 & 0.9 & 1.1 & 0.9 & 0.7 & 0.8 & 0.7 & 1.2 & 1.3 & 0.9 & 0.7 & 1.3 & 0.93 \\
\hline Sn & 0.4 & 0.4 & 0.3 & 0.5 & 0.3 & 0.4 & 0.4 & 0.5 & 0.5 & 0.3 & 0.3 & 0.5 & 0.4 \\
\hline $\mathrm{Sb}$ & 1.5 & 1.3 & 1.3 & 1.5 & 2.1 & 1.9 & 1.8 & 1.7 & 1.8 & 1.9 & 1.3 & 2.1 & 1.68 \\
\hline | & 11.8 & 12.5 & 12 & 13.1 & 11.8 & 12.8 & 13.1 & 12.7 & 11.9 & 11.5 & 11.5 & 13.1 & 12.32 \\
\hline Cs & 16.8 & 17.3 & 17.5 & 15.4 & 16.8 & 18.1 & 17.3 & 19.1 & 16.7 & 16.5 & 15.4 & 19.1 & 17.15 \\
\hline $\mathrm{Ba}$ & 70.2 & 75 & 78 & 80 & 79 & 82 & 75.4 & 77.3 & 78.6 & 75.2 & 70.2 & 82 & 77.07 \\
\hline La & 11.2 & 12 & 11.7 & 12.4 & 13.1 & 12.3 & 14.2 & 12.5 & 12.7 & 11.4 & 11.2 & 14.2 & 12.35 \\
\hline $\mathrm{Nd}$ & 4.3 & 4.1 & 5.2 & 5.3 & 4.9 & 4.3 & 3.9 & 3.7 & 4.6 & 4.9 & 3.7 & 5.3 & 4.52 \\
\hline $\mathrm{Sm}$ & 5.4 & 5.9 & 5.7 & 5.2 & 6.7 & 4.9 & 5.6 & 6.5 & 4.8 & 5.6 & 4.8 & 6.7 & 5.63 \\
\hline $\mathrm{Hf}$ & 1.9 & 1.1 & 1.8 & 2.1 & 1.9 & 1.9 & 1.5 & 2.4 & 2.4 & 2.3 & 1.1 & 2.4 & 1.93 \\
\hline W & 2.2 & 2.5 & 3.1 & 2.4 & 1.9 & 3.2 & 2.8 & 2.7 & 2.5 & 2.8 & 1.9 & 3.2 & 2.61 \\
\hline $\mathrm{Bi}$ & 0.8 & 0.8 & 0.6 & 0.7 & 0.5 & 0.9 & 0.4 & 0.4 & 0.6 & 0.8 & 0.4 & 0.9 & 0.65 \\
\hline U & 4 & 4 & 5 & 4.5 & 5.2 & 4.9 & 5.9 & 4.8 & 4.5 & 5 & 4 & 5.9 & 4.78 \\
\hline Th & 5.8 & 5.9 & 6.5 & 6.1 & 5.8 & 5.5 & 6.3 & 6.4 & 6.6 & 6.2 & 5.5 & 6.6 & 6.11 \\
\hline$\sum$ REE & 870.00 & 977.14 & 853.95 & 933.56 & 972.56 & 964.38 & 894.93 & 992.2 & 926.19 & 975.61 & 764.3 & 1050.5 & 936.35 \\
\hline Nor. Calc. & 90.74 & 57.49 & 86.05 & 91.67 & 90.74 & 86.15 & 91.40 & 88.37 & 89.97 & 68.61 & 57.49 & 91.67 & 84.12 \\
\hline
\end{tabular}


Table 1 Chemical analysis data of major oxides (\%) and trace rare earth elements (ppm), of the studied rocks (Continued)

\begin{tabular}{llllllllllllll}
\hline & 1 & 2 & 3 & 4 & 5 & 6 & 7 & 8 & 9 & 10 & Mim. & Max. & Average \\
\hline Nor.Dolo. & 6.82 & 2.11 & 4.41 & 1.67 & 7.34 & 8.05 & 5.37 & 4.02 & 4.39 & 4.27 & 1.67 & 8.05 & 4.85 \\
LREEs & 21.4 & 22.4 & 23 & 23.2 & 25.2 & 22 & 23.76 & 22.73 & 22.14 & 21.95 & 19.73 & 26.7 & 22.78 \\
HREES & 6.2 & 7 & 7.2 & 7.9 & 6.4 & 6.3 & 7.5 & 7.7 & 5.6 & 4.7 & 4.5 & 8 & 6.65 \\
REE/HREES & 3.45 & 3.20 & 3.19 & 2.94 & 3.94 & 3.49 & 3.17 & 2.95 & 3.95 & 4.67 & 4.38 & 3.34 & 3.43 \\
Sr/Ca & 0.00098 & 0.00155 & 0.00104 & 0.00019 & 0.00098 & 0.00104 & 0.00088 & 0.00101 & 0.00099 & 0.00117 & 0.00031 & 0.00097 & 0.00098 \\
\hline
\end{tabular}

and microsparite matrix. Some of the microcrystalline matrix is stained by iron oxy-hydroxides and exhibits re-crystallization to microsparite. Allochems are mainly represented by abundant nummulites species, Nummulite gizehensis and Nummulite discorbinus, as well as amounts of gastropods, pelecypods, miliolids, bryozoa, and others (Figs. 4 and 5). This microfacies shows considerable variation in the size of the allochems. The large nummulite size possibly indicates higher salinity and adequate paleoecologic conditions (Plumley et al. 1962) and presumably characteristic of warm open marine condition (Wilson 1975). The sand content is monocrystalline, fine to medium, subangular to subrounded quartz grains scattered in the matrix.

\section{Nummulitic biosparite (grainstone) microfacies}

The allochems content are represented by nummulites (50-70\%), and other fossils are embedded in sparite matrix (grainstone). Nummulites vary from 10 to $25 \mathrm{~mm}$ in diameter (Fig. 6). The nummulites are leached and later on filled with sparry calcite or micrite, and some are stained with iron oxy-hydroxides. Those retaining their original fibrous structure are occasionally present.

\section{Nummulitic rudstone}

The rudstone microfacies is made up of nummulites (30 to $40 \%$ ), foraminifera (3\%), and quartz grains (5 to $6 \%$ ). Allochems are embedded and cemented with sparry calcite (Fig. 7). Nummulites reach up to $35 \mathrm{~mm}$ in diameter. Some foraminifera and miliolids are enclosed in microsparite cement. The allochems (fossils) are mostly filled with sparry calcite, but a few miliolids and algae are micritized and have a micritic envelope (Fig. 8). Monocrystalline and polycrystalline, medium to coarse, subangular to rounded quartz grains are embedded in the matrix.

\section{Pelecypod biomicrite (wacke/packstone) microfacies}

This microfacies is present in the upper part of the studied section in Thebes Formation. The allochems are represented mainly by pelecypod shells (35\%), and few algae and micritic peloids are present. This association is texturally considered as a biomicrite (wacke to packstone) in a matrix (Fig. 9). The sediments are loosely packed inferring that cementation occurred before significant compaction. Micrite envelope outlined the skeletal grains of pelecypods, with microsparite pore-filling.

\section{Biomicrite dolomitic lime-mudstone microfacies}

The fossils are only allochems in this microfacies (20\%). They are mainly of nummulites species, miliolids, and other shell fragments scattered in the micritic matrix (Fig. 10). This microfacies is characterized with fine anhedral crystals, closed packing, and intercrystalline porosity.

\section{Diagenesis}

Carbonate rocks are particularly susceptible to diagenesis partly because minerals are more soluble in water and so are subject to dissolution and re-precipitation. The main diagenetic features encountered in the carbonate rocks of Geble El Gurna are described below:

\section{Cementation}

Two types of micrite and microsparite cementation are recorded in the studied samples. Micrite and sparite cemented the allochems together, (Figs. 4 and 5), which indicated that it had taken place when the pore-fluid becomes supersaturated with respect to cement phase (Tucker and Wright 1990). Micrite and microsparite are also observed to be filling the intergranular pores and lining the chambers of bioclastics (Figs. 4, 6, and 8). Micrite is of early diagenetic marine origin (Longman 1980). The original micrites were occasionally replaced by coarser mosaics of microspar through aggrading neomorphism. This cement is early diagenetic formed in the phreatic zone.

\section{Neomorphism}

Neomorphism is demonstrated where former aragonite bioclasts have been calcitised-retaining elements of the original structure (Figs. 5 and 6). The nummulite, foraminiferal, and pelecypoda shells were re-crystallized to unequigranular microspar crystals before leaching. While some algae and millolids were re-crystallized to equigranular microspar, also some other shell fragments were re-crystallized to sparry calcite. The re-crystallization is typically associated with crystal growth and transformation of the metastable $\mathrm{Mg}$-calcite and aragonite to calcite under meteoric and burial diagenetic environments (Tucker and Wright 1990). Thus, the original micrites 







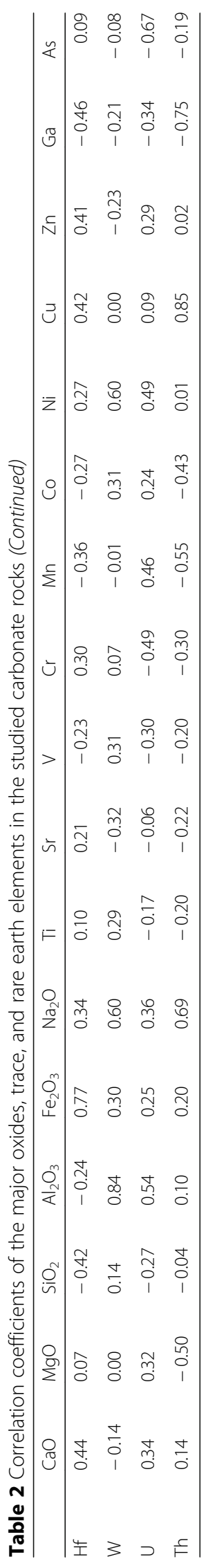




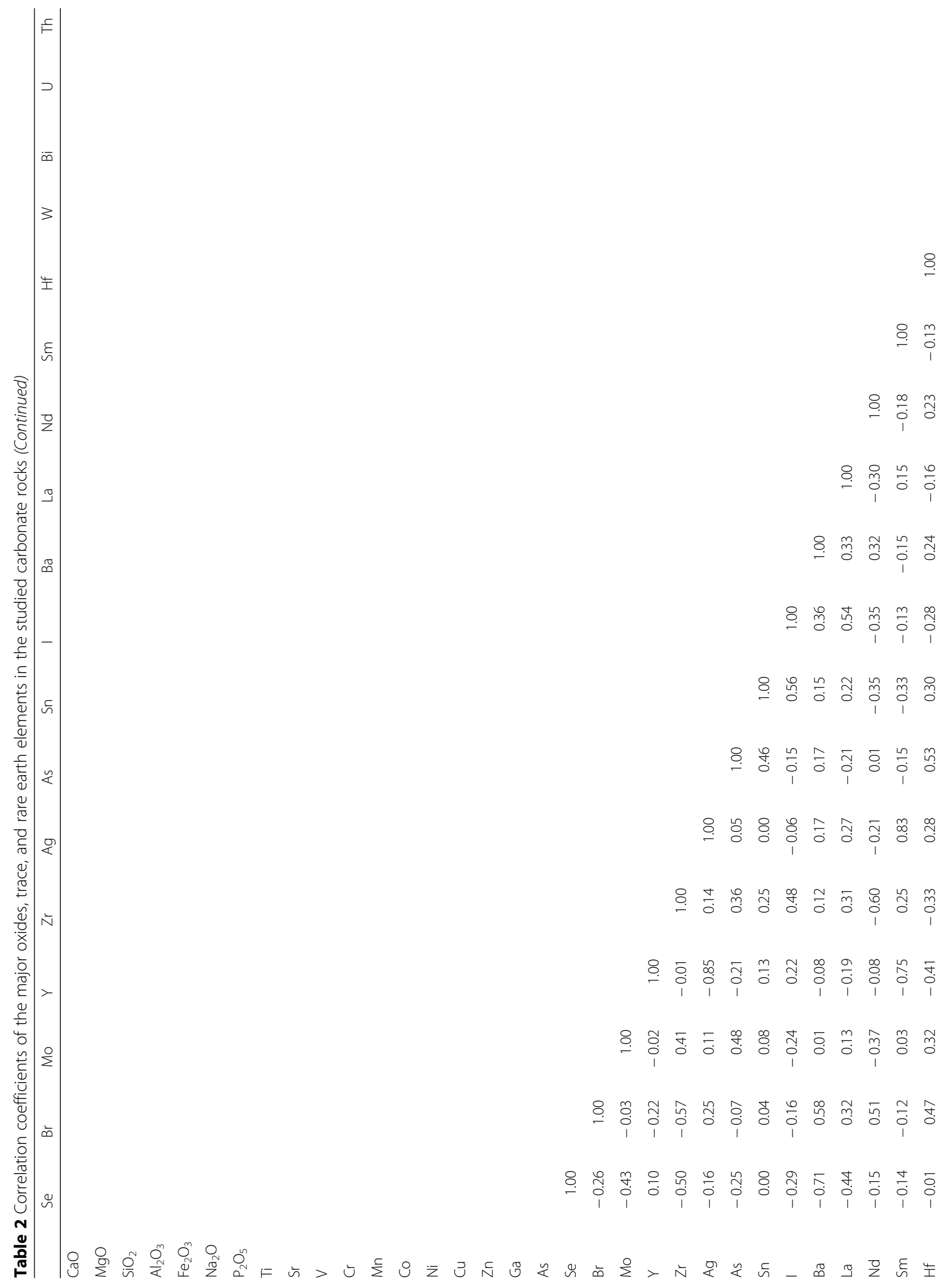




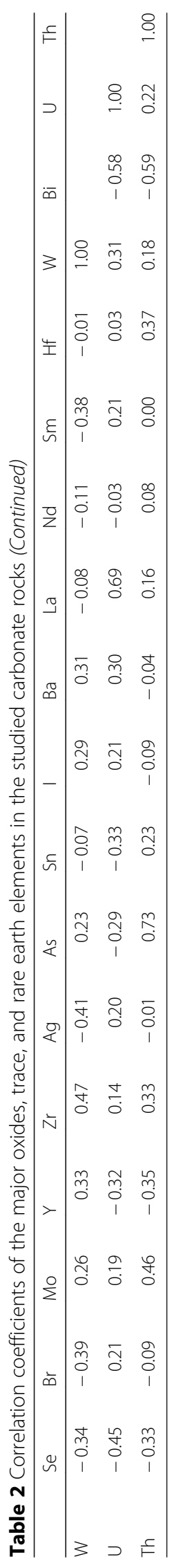




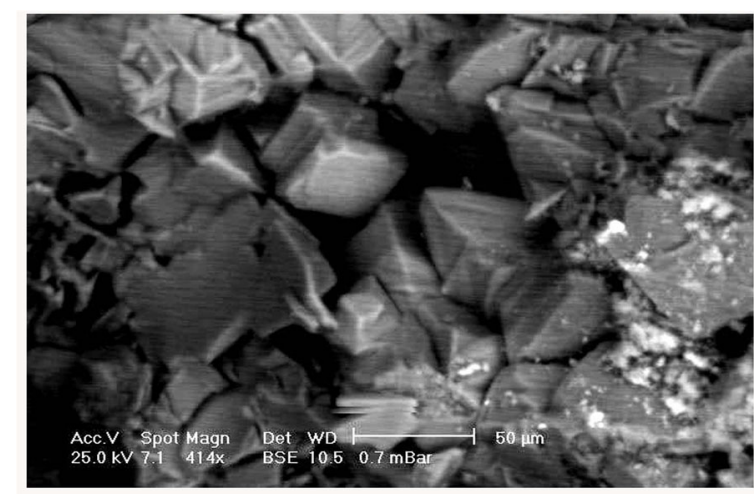

\begin{tabular}{|l|l|lllllllllll}
\hline Element & $\mathrm{Ca}$ & $\mathrm{Mg}$ & $\mathrm{Si}$ & $\mathrm{Al}$ & $\mathrm{Fe}$ & $\mathrm{Na}$ & $\mathrm{K}$ & \multicolumn{2}{c|}{$\mathrm{Cl}$} \\
\hline wt. $\%$ & 16.5 & 15.41 & 14.31 & 10.74 & 8.54 & 20.1 & 2.1 & 12.2
\end{tabular}

Fig. 3 BSE image and EDX analysis data showing the dolomite crystals is up to $80 \mu \mathrm{m}$ and patches of halite

were transformed to coarser mosaics of microspar through aggrading neomorphism.

Bioclastics which are made originally of aragonite may be dissolve in most cases during diagenesis and are filled with micrite (Figs. 8 and 10). This micritization process took place at or just below the sediment-water interface (Tucker and Wright 1990). Margins of some nummulites, millolids, and pelecypods become completely micritized forming a micrite envelope (Fig. 8), which points to deposition under a shallow water regime at an early stage of diagenesis (Bathurst 1975).

\section{Compaction}

The effect of mechanical compaction on carbonate sediments was decreased by early cementation either in the marine environment or during meteoric diagenesis (Tucker and Wright 1990) Mechanical compaction is clearly observed in the closer packing of bioclastics, also showing penetration and reduction of shell fossil fragments (Figs. 8, 9 , and 10). It is suggested that the compaction has initiated

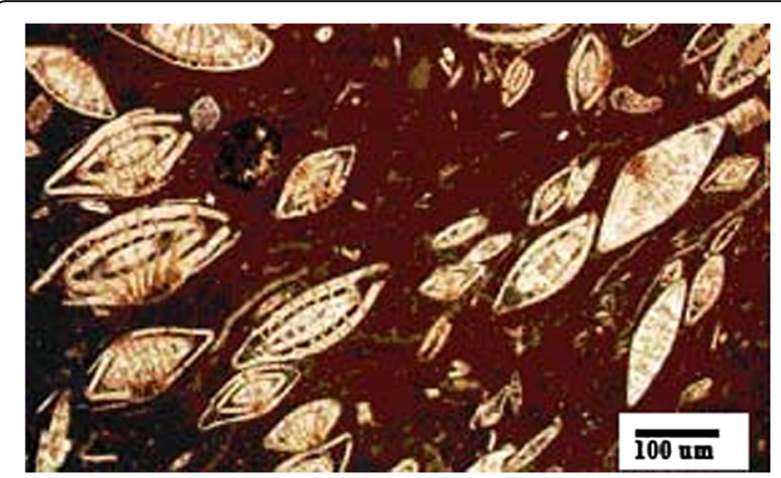

Fig. 4 Nummulitic biomicrite (wackestone/mudstone) microfacies showing Nummulite gizehensis, as well as amounts of gastropods and others scattered in micritic matrix, PPL

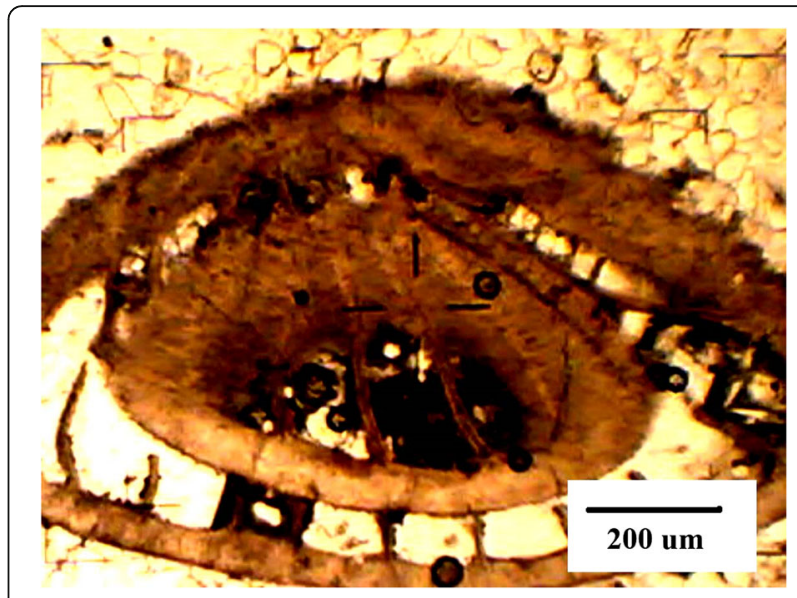

Fig. 5 Nummulitic biomicrite (wackestone/mudstone) microfacies showing Nummulite discorbinus embedded in sparite matrix and dissolution, PPL

at an early stage before complete cementation (cf. Adams and Mackenzie 1998).

\section{Dissolution}

Under the effect of the meteoric waters, the unstable mineral suite consisting of aragonite and magnesian calcite (metastable phases) changes to stable phase and re-precipitated by the dissolution process. Dissolution plays a little role in the diagenesis of the carbonate rocks of Geble El Gurna. This process involves partial or, rarely, completes leaching of some fossils and shell fragments as well as some vugs and micro-channels in the matrix due to tectonic effect (Figs. 5 and 6). Dissolution takes place mostly in the near-surface meteoric condition (Tucker and Wright 1990). The dissolution processes and secondary porosity indicate early diagenetic stage. Selective destruction and void formation are due

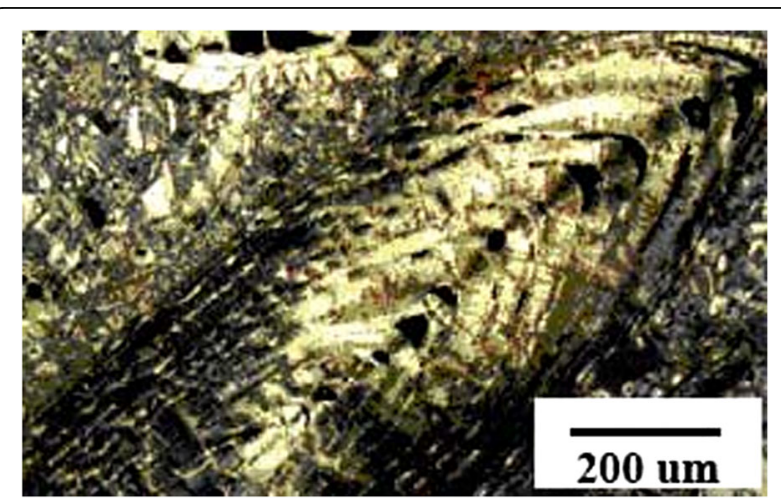

Fig. 6 Nummulitic biosparite (grainstone) showing Nummulite gizehensis are embedded in sparite matrix (grainstone) as well as compaction and dissolution. Note: Nummulite gizehensis filled with sparry calcite and micrite, PPL 


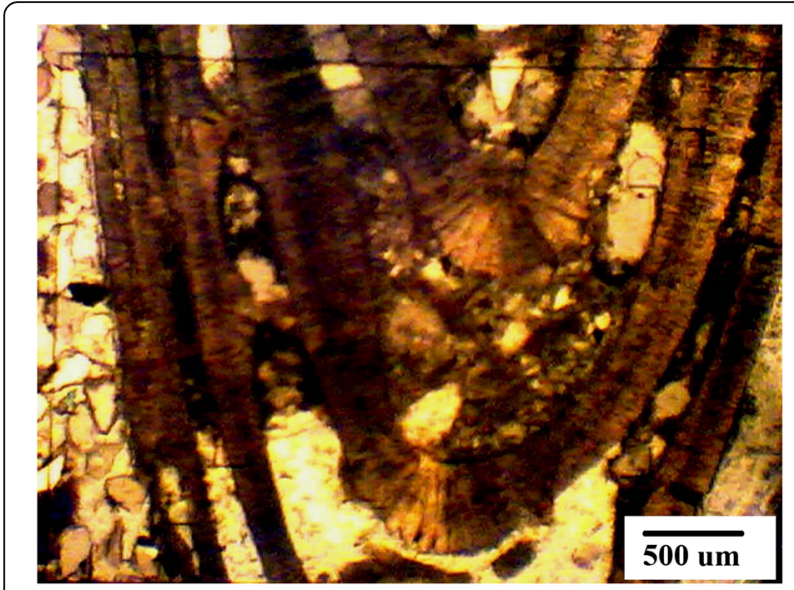

Fig. 7 Nummulitic rudstone microfacies showing Nummulite gizehensis embedded in sparry calcite matrix, PPL

to the solubility of the shells. Generally, this rock type indicates shallow marine subtidal environment.

\section{Dolomitization}

Magnesium is pronounced in the succession in all samples. The neomorphism of high magnesian-calcite foraminiferal tests, algae, and miliolids to calcite evolves $\mathrm{Mg}^{2+}$, which plays a significant role in the dolomitization process (Maliva and Dickson 1994). The possible sources of $\mathrm{Mg}$ ions required to initiate dolomitization could be transformations of metastable $\mathrm{Mg}$-calcite and aragonite to calcite upon deep burial seawater and/or connate Mg-bearing water circulating through sediments. The dolomite rhombs are unimodal and polymodal, idiomorphic to hypidiomorphic, and equigranular in texture with crystal size ranging from 10 to $80 \mu \mathrm{m}$ (Fig. 3). The dolomite rhombs are fine crystalline and unzoned, and the author suggests that dolomitization of the studied

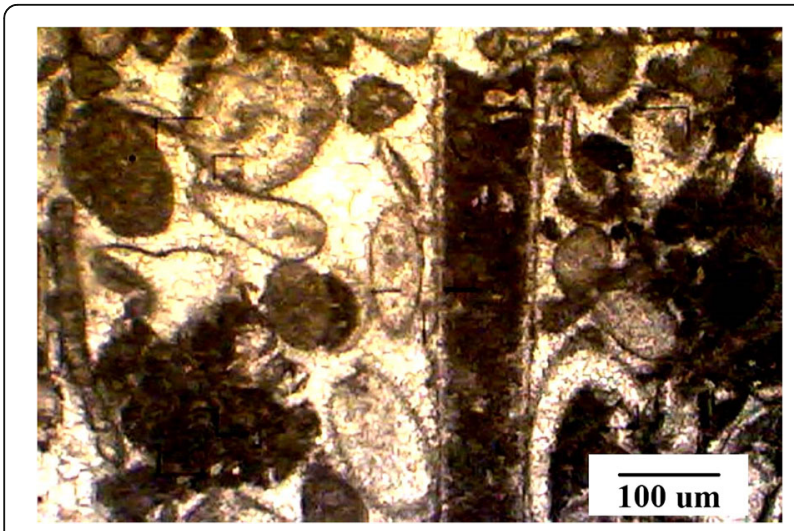

Fig. 8 Nummulitic rudstone microfacies showing the fossils are mostly filled with sparry calcite, but a few miliolids and algae are micritized and have a micritic envelope. Note: Compaction and the micritic envelope, PPL

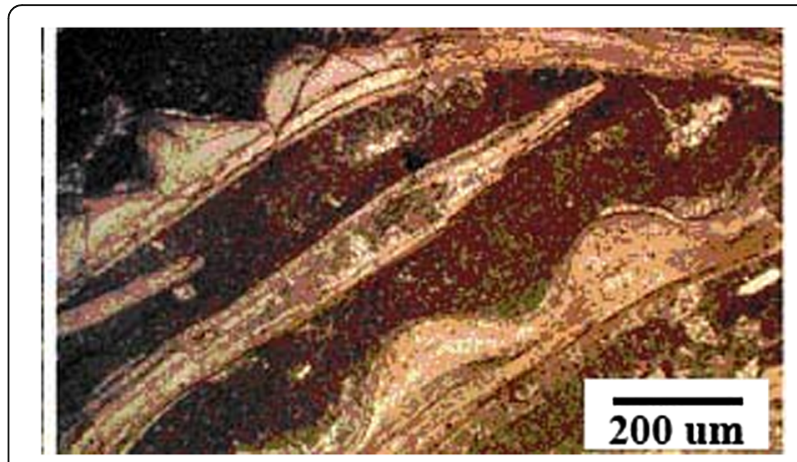

Fig. 9 Pelecypod biomicrite (wacke/packstone) microfacies showing a mega-sized pelecypod embedded in micritic matrix as well as a compaction effect, PPL

carbonate rocks is most probably post-depositional and took place in the mixing zone between meteoric and marine phreatic zones.

\section{Geochemistry}

Chemical analysis data of major, trace, and rare earth elements are listed in Table 1 . Normative calcite content varies from 57.49 to $91.76 \%$, averaging $84.12 \%$, while the normative dolomite content ranges from 1.67 to $8.05 \%$, averaging $4.85 \%$. Calcite precipitated from seawater would contain from 5.9 to $27.1 \% \mathrm{MgCO}_{3}$ by weight. While calcite exposed to meteoric water diagenesis will lose most of its magnesium content (Moore 1989; Morse and Mackenzie 1990). The studied rocks contain $4.76 \%$ $\mathrm{MgCO}_{3}$, in average, indicating that the studied calcite subjected to progressive diagenesis, which led to loose most of its magnesium content under meteoric water. $\mathrm{MgO}$ content ranges from 0.8 to $3.85 \%$. It seems more eligible that the dolomitization process is controlled by

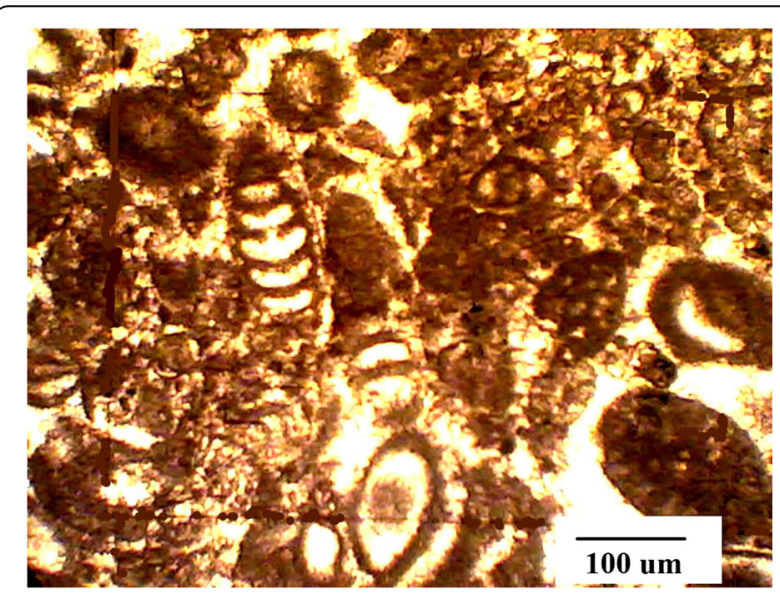

Fig. 10 Biomicrite dolomitic lime-mudstone microfacies showing of nummulites species, miliolids, and others shell fragments scattered in the micritic matrix. Note: Compaction and the micritic envelope, PPL 
the fracture and joint systems in the area, which maintain access to the dolomitizing fluids. Positive correlation $(r=0.41)$ between $\mathrm{Ca}$ and $\mathrm{Mg}$ indicated calcite is present as calcite and dolomite (Table 2 ), which agrees with $\mathrm{X}$-ray results.

$\mathrm{SiO}_{2}$ content in the studied samples ranges from 1.25 to $5.33 \%$ expected samples number 2 and 10, which represented limestones with nodular flint. The highest $\mathrm{SiO}_{2}$ value is detected at the top bed of the succession indicating an upward increase in the influx of terrigenous constituent of the depositional basin.

The carbonate rocks of the studied succession record a low content of $\mathrm{Al}_{2} \mathrm{O}_{3}$ and $\mathrm{K}_{2} \mathrm{O}$ (average 1.64 and 0.03\%; respectively). The low content of both $\mathrm{Al}_{2} \mathrm{O}_{3}$ and $\mathrm{K}_{2} \mathrm{O}$ can mainly be attributed to the low clay content. $\mathrm{Si} / \mathrm{Al}$ ratio is about 3 (without S. Nos. 2 and 10), suggesting a three-layer clay structure. Moreover, the preponderance of $\mathrm{K}$ indicates possible smectite-illite mixed layer.

$\mathrm{Fe}_{2} \mathrm{O}_{3}$ content of the studied carbonate rocks ranges from 0.64 to $0.91 \%$, averaging $0.81 \%$ (Table 1 ). The low values for the Geble El Gurna carbonate rocks indicate the formation of dolomite in the near-surface oxidizing environment (Choquette and James 1990). Positive correlation $(r=0.42$, Table 2) between $\mathrm{Fe}_{2} \mathrm{O}_{3}$ and $\mathrm{MgO}$ indicates that iron may be associated with dolomite. Also, the positive correlation between $\mathrm{Fe}_{2} \mathrm{O}_{3}$ and $\mathrm{Sr}(r=0.38)$ indicates that iron oxy-hydroxides may be scavenge and uptake $\mathrm{Sr}$, which is an essential function of many microbes. This is in agreement with Krumbein (1983), Abou El-Anwar (2005, 2011, 2014, and 2016), and Abou El-Anwar et al. $(2017,2018)$.

Trace element data of sedimentary carbonate rock can be used to constrain the chemical composition of ancient seawater (Veizer and Mackenzie 2014; Kamber et al. 2014). Sodium is present in the carbonate rocks sodium co-precipitated with the carbonate minerals, which gives an indication of salinity of water from which the original carbonates were deposited (Moore 1989; Morse and Mackenzie 1990). $\mathrm{Na}_{2} \mathrm{O}$ content of the studied samples ranges from 0.1 to $0.12 \%$, averaging $0.15 \%$. Na content may be attributed to the presence of halite which is conformed with the X-ray results. There are positive correlation between $\mathrm{Na}$ and $\mathrm{Cl}(r=0.55$, Table 2), which indicate high salinity during precipitation, so the studied area effected by dry climate, in agreement with the petrographic study. Sodium occurs in modern carbonate sediments to levels of about 3000 ppm and progressively drops with diagenesis to $200 \mathrm{ppm}$ in ancient limestone (Scoffin 1987). The sodium content of the studied carbonates ranges from 800 to $1394 \mathrm{ppm}$, averaging $1100 \mathrm{ppm}$. This means that there is loss in $\mathrm{Na}$ content during diagenesis of the studied carbonate rocks. Therefore, the diagenesis processes may have taken place in an environment less saline than seawater (Loukina and Abou El-Anwar 1994; Loukina et al. 2001; Abou
El-Anwar 2006; Abou El-Anwar 2011). This agrees with the environments of dolomitization in mixed marine/ meteoric water (Badiozamani 1973).

The strontium content for the majority of the ancient carbonate is less than $500 \mathrm{ppm}$ (Bathurst 1975). The Sr-contents of Geble El Gurna ranges from 400 to $520 \mathrm{ppm}$, averaging $483 \mathrm{ppm}$, which indicated that the dolomite crystals deposited in mixing zone of marine and meteoric water (Table 1). The depletion in $\mathrm{Sr}$ content can be attributed to the long diagenetic history particularly the dolomitization stages. This agrees with the findings of Brand and Veizer (1980); Loukina and Abou El-Anwar (1994). Strontium concentrations can be utilized for understanding the nature of the dolomitize fluid. Remnant inclusions of precursor carbonate (calcite or aragonite) and distribution coefficient of Sr (Dsr) between dolomite and diagenetic fluids are generally the major factors controlling the $\mathrm{Sr}$ concentrations in dolomite (Budd 1997). Therefore, the dolomites reflect mostly the nature of the dolomitize fluid. Estimates of $\mathrm{Sr}$ distribution coefficient (Dsr) for dolomite vary from 0.015 to 0.06 (Vahrenkamp and Stewart 1990; Banner 1995; Budd 1997). If the Sr content were mainly due to Dsr and $\mathrm{Sr} / \mathrm{Ca}$ of the dolomitize fluid, the latter can be calculated from equation $(\mathrm{Sr} / \mathrm{Ca})$ dolomite $=\mathrm{Dsr}(\mathrm{Sr} / \mathrm{Ca})$ fluid. Such calculations yield molar $\mathrm{Sr} / \mathrm{Ca}$ for the Geble El Gurn dolomitization fluid of 0.00031 to 0.000974 with average 0.000984 . These values are significantly less than the $\mathrm{Sr} / \mathrm{Ca}$ ratio of present day seawater (0.0086; Drever 1988). Thus, the average $\mathrm{Sr}$ value suggesting that we are dealing with $\mathrm{Sr}$-depleted dolomitizing fluids, likely due to partial or full meteoric water contributions (Abou El-Anwar 2010, 2012; Abou El-Anwar and Mekky 2013).

However, post-depositional diagenetic and metamorphic processes may modify the mineralogical compositions, concentrations of mobile trace elements (Webb et al. 2009). The fluid-immobile elements, such as the rare earth elements (REEs) and high-field strength elements (HFSE), remain largely unaffected by diagenesis (Webb et al. 2009); thus, they are useful for recognize the ancient environmental conditions. The mean values of the $\Sigma$ REEs for the studied samples are $936 \mathrm{ppm}$. The studied carbonate rocks showed significant enrichment of LREEs and a well-depleted pattern of HREEs (Table 1). The total concentration of total REEs in average bulk continental crust is about 125 ppm (Rudnick and Gao 2003). Thus, geochemical pattern of the studied samples mentioned that high solubility and mobility potential of LREEs compared with HREEs, resulting in good fractionation and enrichment of these elements in the depositional environment. So, the concentration of the (LREEs) is higher than that of (HREEs), which is in conformance to the general distribution of REEs in shale or limestone (Gromet et al. 1984; Condie 1991; Ketris and Yudovich 2009). 
The concentrations of REEs in ocean waters reflect different inputs, such as river and eolian flux (Zhao et al. 2009), hydrothermal alteration of oceanic crust (Michard and Albarede 1986), and diagenesis (Derry and Jacobsen 1990). Thus, the study of REE concentrations of the studied carbonate rocks is a useful tool to define the depositional environment; fresh water or marine conditions (cf. Bolhar and Van Kranendonk 2007), hydrothermal input (cf. Derry and Jacobsen 1990; Allwood et al. 2010), and redox conditions (De Baar et al. 1988; Elderfield 1988; Kato et al. 2002). The primary distribution pattern of REEs in many carbonates has survived irrespective of their age, provenance, post-depositional processes, and metamorphic grade (Bau and Möller 1993; Webb et al. 2009).

Positive values of $\mathrm{La}$ and $\mathrm{Ga}$ are a common feature of seawater (Bau et al. 1997; Alibo and Nozaki 1999) which suggested that the higher stability of them in seawater relative to neighboring REEs during scavenging. Thus, La and $\mathrm{Ga}$ content indicated that the investigated carbonate rocks were deposited in marine environment. Metals may be depleted resulting to REE oxidation state and mobility under different oxidation-reduction conditions (Wang and Liang 2014; Abou El-Anwar et al. 2018). A positive relation between $\mathrm{Fe}$ with $\mathrm{Hf}, \mathrm{Br}, \mathrm{As}, \mathrm{I}, \mathrm{Ba}, \mathrm{Nd}$, and W indicates that iron is increasing the buffer capacity of the studied carbonate matrix; therefore, these REE may be co-precipitated with Fe.

Thus, light REEs are scavenged preferentially from the water condition compared to the heavy REEs (De Baar et al. 1985; German and Elderfield 1990; German et al. 1991). Thus, this process in the studied carbonate rocks is resulting for dissolved REEs in oxic seawater under redox behavior (De Baar et al. 1985, 1988; Byrne and Sholkovitz 1996).

The total radioactivity measurements are ranging from 4 to $5.9 \mathrm{ppm}$ for $\mathrm{U}$ and from 5.5 to $6.6 \mathrm{ppm}$ for Th. The radioactivity measurements are less than the background level of carbonates, and they are in the allowed limits for carbonate rocks and representative of less contaminated samples. Thus, the investigated carbonate rocks can be used in cement industries and as building stones (cf. Abou El-Anwar et al. 2017; Abou El-Anwar 2018).

\section{Conclusions}

The carbonate rocks of Gebel El-Qurn, west Luxor were deposited under shallow, warm open marine environment, as witnessed by the large number of shallow marine fauna (forminifera, gastropods, pelecypods, miliolids) besides algae and echinoid fragments. Also, the occurrence of nummulites indicated that these rocks were deposited under a shallow, subtidal-intertidal, warm marine environment.

The microfacies association of the studied carbonate sediments is grouped into (1) nummulitic bioclastic wackestone/mudstone, (2) nummulitic biosparite grainstone,
(3) nummulitic rudstone microfacies, (4) pelecypod biomicrite wacke/packstone, and (5) biomicrite dolomitic lime-mudstone. The main diagenetic processes affecting the Lower Eocene Thebes Formation are as follow: cementation, neomorphism, compaction, dissolution, and dolomitization. Diagenesis occurred under submarine and subaerial environments. The submarine environment resulted in the formation of micritic envelope, micritization, micritic cement, compaction, and dolomitization. The subaerial diagenesis is manifested by the presence of extensive cementation, neomorphism, and dissolution.

The large nummulite size reflects deposition in a shallow, warm and open marine environment. The fine and medium quartz grains in the sediments are mostly angular to subrounded indicating that they were transported by streams and deposited in an environment characterized by a low average kinetic energy. The quartz grains are monocrystalline, which most probably represents an igneous source.

The dolomite rhombs recorded in the sediments range in a diameter from 10 to $80 \mu \mathrm{m}$. The formation of the dolomite took place in a near-surface environment and from less saturated solutions.

Mineralogically, the studied carbonate rocks consist mainly of calcite, dolomite as well as quartz, halite, pyrite and clay minerals. The studied dolomite samples are generally non-stoichiometric being formed from solutions with lower $\mathrm{Mg} / \mathrm{Ca}$ ratio in a mixed zone.

Geochemically, $\mathrm{SiO}_{2}$ record higher value at the top beds of the studied succession, suggesting an upward increase in the influx of terrigenous constituents to the basin of deposition. The low iron content of the studied dolomite indicates precipitation under near-surface oxidizing environment. However, the low co-precipitated $\mathrm{Na}$ and $\mathrm{Sr}$ than the normal salinity of seawater, means possible loss in $\mathrm{Na}$ and $\mathrm{Sr}$ content during diagenesis. Therefore, the diagenetic processes may have taken place in an environment less saline than sea water besides; the dolomites were precipitated under mixed marine/meteoric water environment. LREEs are higher than HREEs and concentrated under redox condition. The radioactive $\mathrm{Th}$ and $\mathrm{U}$ are less than the background level of carbonates, and they are in the permissible limits for carbonates.

\section{Acknowledgements \\ The authors would like to thank the Geological Sciences Dept., National Research for its facilitates during this work.}

Authors' contributions

All authors contributed equally in all article steps. All authors read and approved the final manuscript.

Ethics approval and consent to participate Accepted.

Consent for publication Accepted. 


\section{Competing interests}

The authors declare that they have no competing interests.

\section{Publisher's Note}

Springer Nature remains neutral with regard to jurisdictional claims in published maps and institutional affiliations.

\section{Received: 10 July 2018 Accepted: 27 August 2018}

\section{Published online: 01 October 2018}

\section{References}

Abou El-Anwar EA (2005) Petrography, geochemistry and genesis of the Upper Eocene carbonate terraces (II and III), Qasr El-Sagha Formation, El-Faiyum, Egypt. Sedimentology of Egypt 13:243-260

Abou El-Anwar EA (2006) Petrography, geochemistry and genesis of some Middle Eocene rocks at Qattamia area, Cairo-Suez Road, Egypt. NRC, Egypt 31(6):519-543

Abou El-Anwar EA (2010) Petrographical, geochemical and environmental studies of the subsurface carbonate sediments of El-Azima Well, western Samalut, Samalut Formation, El-Minia, Egypt. Sedimentol Egypt 18:98-100

Abou El-Anwar EA (2011) Petrographical, geochemical and diagenetic studies of the middle Eocene carbonates Mokattam Formation of Darb ElFayium area, vol 80. International Conference on Geological and Engineering, Paris, pp 1315-1325

Abou El-Anwar EA (2012) Contribution to the composition and origin of the reef Terraces in Ras Mohamed, Sharm El-Sheikh Coast, Southern Sinai, Egypt. Geol Soc Egypt 56:33-48

Abou El-Anwar EA (2014) Composition and origin of the dolostones of Um Bogma formation, Lower Carboniferous, West Central Sinai, Egypt. Carbonates Evaporates 29:239-250

Abou El-Anwar EA. Some carbonate rocks utilized as a building material rocks, Egypt some carbonate rocks utilized as a building material rocks, Egypt, carbonate and evaporates, 2018; Accepted: 26 Jan 2018, https://doi.org/10. 1007/s13146-018-0423-4

Abou El-Anwar EA, Mekky HS (2013) Contribution to the geochemistry, composition and origin of the Dolostones of Um Gheig Formation, Middle Miocene, Red Sea Coast, Egypt. J Appl Sci Res 9(6):3659-3673

Abou El-Anwar EA, Mekky HS, Abdel Wahab W (2018) Geochemistry, mineralogy and depositional environment of black, shales of the Duwi Formation, Qusseir area, Red Sea coast, Egypt. Carbonates Evaporites. https://doi.org/10. 1007/s13146-017-0417-7

Abou El-Anwar EA, Mekky HS, Darweesh HS, Aita SK (2017) Utilization of some Miocene limestones as building materials from Egyptian north western coastal area (Abu-Sir Ridge). Carbonates Evaporates. https://doi.org/10.1007/ s1314 6-016-0326-1

Adams AE, Mackenzie WS (1998) A color atlas of carbonate sediments and rocks under the microscope. Manson Publ. Itd $179 \mathrm{p}$

Alibo DS, Nozaki Y (1999) Rare earth elements in seawater: particle association, shale normalization, and Ce oxidation. Geochim Cosmochim Acta 63(3/4):363-372

Allwood AC, Kamber BS, Walter MR, Burch IW, Kanik I (2010) Trace elements record depositional history of an Early Archean stromatolitic carbonate platform. Chem Geol 270:148-163

Badiozamani K (1973) The Dorag dolomitization model-application to the Ordovician of Wisconsin. J Sediment Petrol 43:965-984

Banner JL (1995) Application of the trace element and isotope geochemistry of strontium to studies of carbonate diagenesis. Sedimentology 42:805-824

Bathurst RGC (1975) Carbonate sediments and their diagenesis. Elsevier, Amsterdam 658p

Bau M, Möller P (1993) Rare earth element systematics of the chemically precipitated component in Early Precambrian iron formations and the evolution of the terrestrial atmosphere-hydrosphere-lithosphere system. Geochim Cosmochim Acta 57:2239-2249

Bau M, Möller P, Dulski P (1997) Yttrium and lanthanides in eastern Mediterranean seawater and their fractionation during redox-cycling. Mar Chem 56:123-131

Bolhar R, Van Kranendonk MJ (2007) A non-marine depositional setting for the northern Fortescue Group, Pilbara Craton, inferred from trace element geochemistry of stromatolitic carbonates. Precambrian Res 155:229-250

Brand V Veizer J (1980) Chemical diagenesis of a multicomponant carbonates systems. 1. Trace elements. J Sed Petrol 50:1219-1236
Budd DA (1997) Cenozoic dolomites of carbonate islands: their attributes and origin. Earth-Sci Rev 42:1-47

Byrne RH, Sholkovitz ER (1996) Marine chemistry an geochemistry of the lanthanides. In: Gschneidner KA Jr, Eyring L (eds) The Handbook on the Physics and Geochemistry of the Rare Earths. Elsevier, Amsterdam, pp 497-593

Choquette PW, James NP (1990) Limestone- the burial digenetic environment. In: Diagenesis (Ed. By I.A. Mcllreath and D.W. Morrow), Geoscience Canada reprint series, vol 4, pp 75-111

Condie KC (1991) Another look at rare earth elements in shales. Geochim Cosmochim Acta 55:2527-2531

De Baar HJW, Brewer PG, Bacon MP (1985) Anomalies in rare earth distributions in seawater: Gd and Tb. Geochim Cosmochim Acta 49:1961-1969

De Baar HJW, German CR, Elderfield H, Van Gaans P (1988) Rare earth element distributions in anoxic waters of the Cariaco Trench. Geochim Cosmochim Acta 52:1203-1219

Derry LA, Jacobsen SB (1990) The chemical evolution of Precambrian seawater: evidence from rare earth elements in banded iron formations. Geochim Cosmochim Acta 54:2965-2977

Drever JI (1988) The geochemistry of natural waters. Prentice Hall, Englewood Cliffs, p 437

El-Bayomi GM (2007) The geomorphological hazards in the archaeological are west of Qena bend. J Appl Sci Res 3(3):175-184

Elderfield H (1988) The oceanic chemistry of the rare-earth elements. Phil Trans $R$ Soc Lond A 325:105-126

El-Kammar AM, Dabous AA, Selim SR (1991) Mineral and chemical composition of Esna Shale in Luxor, Southern Egypt. MERC Ain Shams Univ Earth Sci Ser 5:120-132

Elwaseif AM, Ismail M, Abdalla M, Abdel-Rahman M, Hafez A (2012) Geophysical and hydrological investigations at the west bank of Nile River (Luxor, Egypt). Environ Earth Sci 67:911-921

German CR, Elderfield H (1990) Application of the Ce anomaly as a paleoredox indicator: the ground rules. Paleoceanography 5:823-833

German CR, Holliday BP, Elderfield H (1991) Redox cycling of rare earth elements I the suboxic zone of the Black Sea. Geochim Cosmochim Acta 55:3553-3558

Gromet LP, Dymek RF, Haskin LA, Korotev RL (1984) The "North American shale composite": its compilation, major and trace element characteristics. Geochim Cosmochim Acta 48:2469-2482

Kamber BS, Webb GE, Gallagher M (2014) The rare earth element signal in Archaean microbial carbonate: information on ocean redox and biogenicity. J Geol Soc Lond 171:745-763

Kato Y, Kano T, Kunugiza K (2002) Negative Ce anomaly in the Indian banded iron formations: evidence for the emergence of oxygenated deep-sea at 2.9 2.7 Ga. Resour Geol 52:101-110

Ketris MP, Yudovich YE (2009) Estimations of clarkes for carbonaceous biolithes: world average for trace element contents in black shales and coals. Int J Coal Geol 78:135-148

Krumbein WE (1983) Microbial geochemistry. Blackwell Scientific Publication, p 330

Leisen HV, Plehwe-Leisen E, Verbeek C, Jurgens C, Krause S (2008) Aspects of conservation in the excavation site of the Athribis temple in Egypt. Environ Geol 56:689-697

Longman MW (1980) Carbonate diagenetic textures from near surface diagenetic environments. Am Assoc Petrol Geol 64:461

Loukina SM, Abou El-Anwar EA (1994) Geochemistry of Gebel Ataqa dolostones, Egypt. Geol of Egypt 38:141-156

Loukina SM, Sameeh S, Abou El-Anwar EA (2001) Petrographical and geochemical characteristics of dolostones of Gaber Formation (Pliocene), Ras Banas, Red Sea Coast, Egypt, Bull. NRC, Egypt 26(4):525-540

Maliva RG, Dickson AD (1994) Origin and environment of formation of late digenetic dolomite in cretaceous/tertiary chalk, Northern Sea Centeral Graben. Geological Magazine, Berlin, p 379

Michard A, Albarede F (1986) The REE content of some hydrothermal fluids. Chem Geol 55:51-60

Moore CH (1989) Carbonate diagenesis and porosity, vol 1986. Elsevier Publ. Co., Amsterdam 338p

Morse JW, Mackenzie FT (1990) Geochemistry of sedimentary carbonates. Elsevier Publ. Co., Amsterdam 707 P

Perch-Nielsen K, Sadek A, Barakat MG, Teleb F (1978) Late cretaceous and early tertiary calcareous nannofossils and planctonic foraminifera zones from Egypt. Actes du VI Colloque Africain Micropaleont, Tunis: Annales des mines et de lageologie 28(2):337-403 
Plumley WJ, Risley GA, Graves RW, Kaley ME. Energy index for limestone interpretation and classification, in classification of carbonate rocks, symposium, Ham, W. E., ed, Amer Assoc Petrol Geol Mem. 1962

Rudnick RL, Gao S (2003) Composition of the continental crust. Treatise Geochem 3:1-64

Said R (1962) The geology of Egypt. Elsevier, Amsterdam 377 p

Said R (1990) Quaternary. In: Said R (ed) The geology of Egypt. Balkema, Rotterdam, pp 487-507

Scoffin TP (1987) An introduction to carbonate sediments and rocks. Chapman and Hall, New York

Snavely PD, Garrison RE, Meguid AA. Regional variation of depositional environments in the Thebes formation (Eocene) of Eastern Egypt-response to pre-rift crustal doming: Bulletin AAPG, 1978

Strougo A, Hassaan M (1984) Preliminary Macroinvertebrate Biostratigraphic Zonation of the Lower Eocene of Gurnah, Luxor Area. Ain Shams Sci Bull, Part B, (1982-1983) 24:23-34

Tucker ME, Wright VP (1990) Carbonate sedimentology. Blackwell Scientific Publ, Oxford 482p

Vahrenkamp VC, Stewart PKA (1990) A new distribution coefficient for the incorporation of strontium into dolomite and its implications for the formation of ancient dolomites. Geology 18:387-391

Veizer J, Mackenzie FT (2014) Evolution of sedimentary rocks. In: Holland, H. D., Turekian, K.K., Treatise on geochemistry, 2 ed. In: Mackenzie FT (ed) Sediments, diagenesis, and sedimentary rocks, vol 9. Elsevier-Pergamon Oxford, pp 399-435

Wang L, Liang T (2014) Accumulation and fractionation of rare earth elements in atmospheric particulates around a mine tailing in Baotou, China. Atmos Environ 88:23-29 https://doi.org/10.1016/j.atmosenv.2014.01.068

Webb GE, Nothdurft LD, Kamber BS, Kloprogge JT, Zhao JX (2009) Rare earth element geochemistry of scleractinian coral skeleton during meteoric diagenesis: a sequence through neomorphism of aragonite to calcite. Sedimentology 56:1433-1463

Wilson JL (1975) Carbonate facies in geologic history, vol 471p. SpringerVerlag, Berlin

Wüst RAJ (1995) Geologisch-geotechnische Untersuchungen im Thebanischen Gebirge, Teil Süd, Luxor, Ägypten (M.Sc. thesis). Universität Bern, Bern

Yehia MA. Some aspects of the structural geology and stratigraph of selected parts of the Nile basin of upper Egypt, Egypt, Ph.D. Thesis, Fac. 1973

Yehia MA. Contribution to the geology of Gebel Gurnah, Luxor, Nile Valley Bulletin of the Geological Survey, Egypt, 1986

Zhao YY, Zheng YF, Chen F (2009) Trace element and strontium isotope constraints on sedimentary environment of Ediacaran carbonates in southern Anhui, South China. Chem Geol 265:345-362

\section{Submit your manuscript to a SpringerOpen ${ }^{\circ}$ journal and benefit from:}

- Convenient online submission

- Rigorous peer review

- Open access: articles freely available online

- High visibility within the field

- Retaining the copyright to your article

Submit your next manuscript at $\boldsymbol{\nabla}$ springeropen.com 